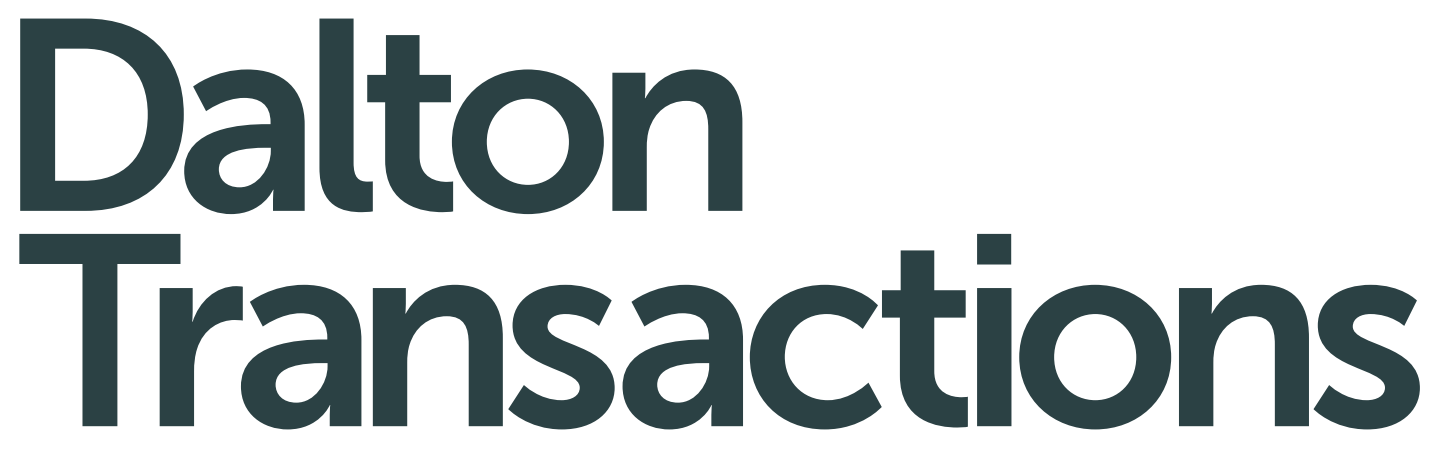

An international journal of inorganic chemistry www.rsc.org/dalton
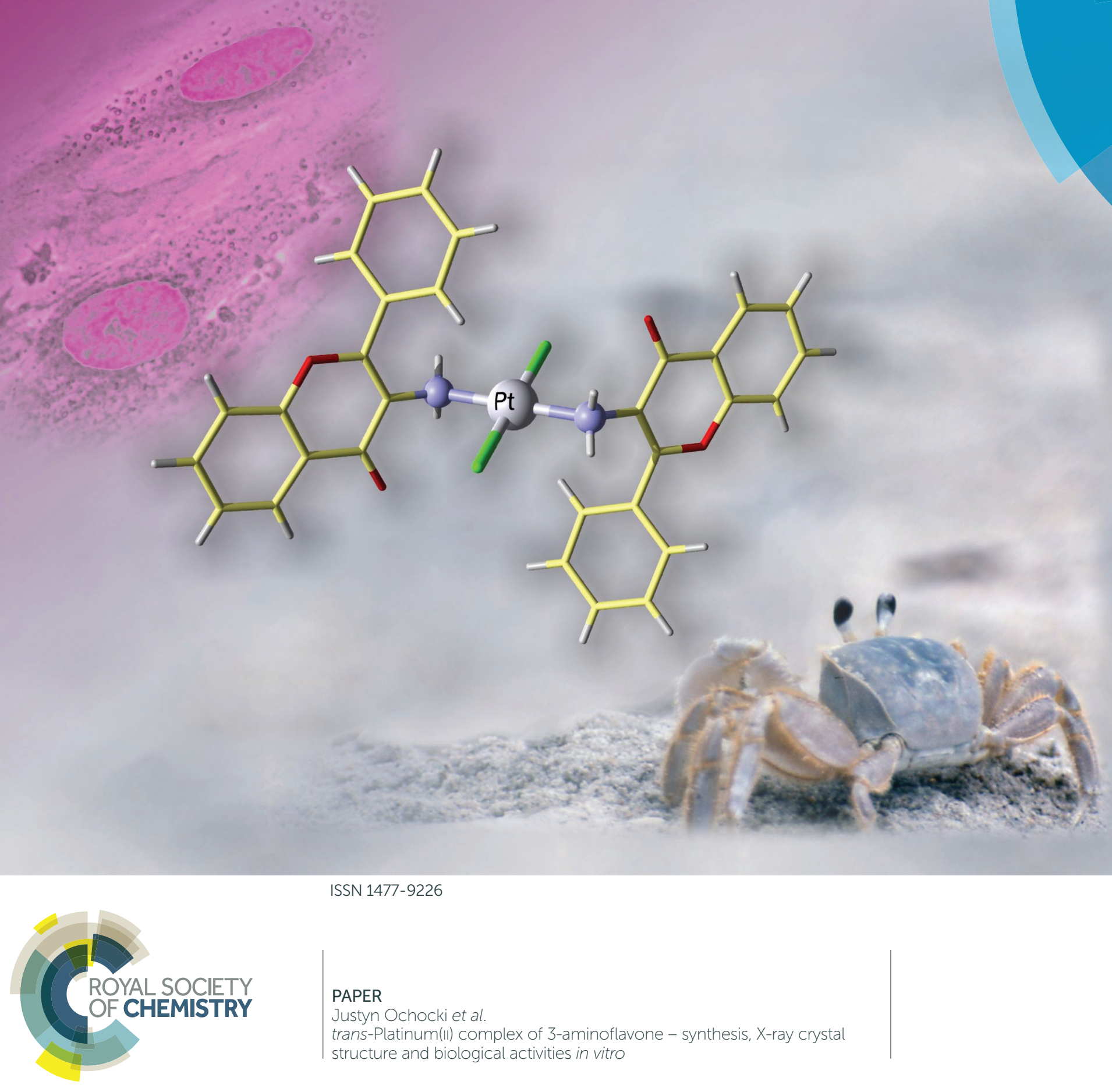


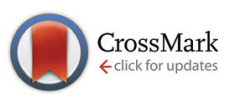

Cite this: Dalton Trans., 2015, 44, 938

Received 22nd May 2014, Accepted 27th July 2014

DOI: $10.1039 / \mathrm{c} 4 \mathrm{dt} 01501 \mathrm{k}$

www.rsc.org/dalton

\title{
trans-Platinum(II) complex of 3-aminoflavone - synthesis, X-ray crystal structure and biological activities in vitro $\uparrow$
}

\author{
Małgorzata Fabijańska, ${ }^{a}$ Kazimierz Studzian, ${ }^{\text {b }}$ Leszek Szmigiero, ${ }^{\mathrm{b}}$ \\ Agnieszka J. Rybarczyk-Pirek, ${ }^{c}$ Arno Pfitzner, ${ }^{\text {d }}$ Barbara Cebula-Obrzut, ${ }^{e}$ \\ Piotr Smolewski, Elżbieta Zyner ${ }^{a}$ and Justyn Ochocki*a
}

\begin{abstract}
This paper describes the synthesis of trans-bis-(3-aminoflavone)dichloridoplatinum(I) (trans-Pt(3-af) ${ }_{2} \mathrm{Cl}_{2}$; TCAP) for use as a potential anticancer compound, and the evaluation of its structure by elemental and spectral analyses, and X-ray crystallography. The complex demonstrated a significant cytotoxic effect against human and murine cancer cell lines, as well as weaker toxicity towards healthy cells (human peripheral blood lymphocytes) in comparison with cisplatin. Various biochemical and morphological methods confirm that the proapoptotic activity of trans- $\mathrm{Pt}(3-\mathrm{af})_{2} \mathrm{Cl}_{2}$ is markedly higher than the reference cisplatin. Our results suggest that trans- $\mathrm{Pt}(3-\mathrm{af})_{2} \mathrm{Cl}_{2}$ may have a different antitumour specificity from that of cisplatin.
\end{abstract}

\section{Introduction}

Metal compounds have been applied in cancer therapy since 1965, when Rosenberg discovered the cytotoxic activity of cis$\mathrm{Pt}\left(\mathrm{NH}_{3}\right)_{2} \mathrm{Cl}_{2}$ (cisplatin). ${ }^{1,2}$ Despite being used for over 30 years since their successful introduction in the clinic, major problems concerned with the side-effects and intrinsic or acquired resistance still remain. ${ }^{3-5}$ The mechanisms underlying resistance to cisplatin may be connected with reduced intracellular accumulation due to reduced drug uptake enhanced efflux, conjugation with intracellular thiols (metallothionein, glutathione), enhanced repair of platinum DNA adducts or changes in molecular pathways involved in regulation of cell survival/cell death. ${ }^{6,7}$ Based on the limitations in the use of the platinum drugs, novel anticancer metal compounds have been designed with the aim of reducing sideeffects or synthesizing drugs with less propensity to induce

\footnotetext{
${ }^{a}$ Department of Bioinorganic Chemistry, 1 Muszyńskiego St. Medical University, 90-151 Eódź, Poland. E-mail: justyn.ochocki@umed.lodz.pl; Tel: +48(42)6779220 ${ }^{b}$ Department of Nucleic Acids Biochemistry, Medical University of Łódź, Mazowiecka 6/8, Lódź, 92-215, Poland

${ }^{c}$ Structural Chemistry and Crystallography Group, Department of Theoretical and Structural Chemistry, University of Lodz, ul. Pomorska 163/165, 90-236 Łódź, Poland ${ }^{d}$ Institut für Anorganische Chemie, Universität Regensburg, Universitätstarsse 31, Regensburg D-93053, Germany

${ }^{e}$ Department of Experimental Hematology, 2 Ciołkowskiego St. Medical University, 93-510 Łódź, Poland

$\dagger$ Electronic supplementary information (ESI) available. CCDC 811964. For ESI and crystallographic data in CIF or other electronic format see DOI: 10.1039/c4dt01501k
}

drug resistance. ${ }^{8}$ Early structure-activity relationship studies suggest that the leaving groups, generally chloride, and two ammine ligands in platinum complexes must be in a cis-configuration and that the corresponding trans-compounds are inactive. Nevertheless, since the 1990s, many trans-platinum compounds have found use as potential drugs. Several scientific groups have reported trans-Pt compounds with in vitro growth inhibitory and in vivo antitumor properties. ${ }^{9,10}$ More importantly, some of these complexes have been found to retain considerable efficacy against tumor cells resistant to cisplatin. ${ }^{11-15}$ Over the recent years, alternative approaches were also focused upon metal complexes with ligands which are important in medicinal and biological systems. Derivatives of flavonoids known to possess diverse biological and pharmacological properties are particularly interesting ligand candidates, in that they are cytotoxic to cancer cells but have no or insignificant activity in normal cells. In addition, their antioxidant, anti-inflammatory, antimicrobial and antiviral activities have aroused great interest as candidates for the synthesis of flavonoid synthetic derivatives. ${ }^{16,17}$ After all aminoflavone [NSC686288; AFP464, NSC710464] is a new antitumour agent, that is currently undergoing phase II clinical trials. This compound demonstrated antiproliferative effects in MCF-7 human breast cancer cells mediated by the aryl hydrocarbon receptor. Furthermore, the compound exhibits antitumor activity in vitro and in vivo against neoplastic cells of the renal origin. ${ }^{18}$

The potential synergistic effect between flavonoids and metal ions as well as trans-geometry in platinum anti-tumour complexes prompted us to synthesize trans-Pt(3-af) $)_{2} \mathrm{Cl}_{2}$ (3-af 3-aminoflavone), denoted as TCAP. Furthermore, we were 
encouraged by the promising anticancer properties of its geometric isomer (cis-Pt(3-af $\left.)_{2} \mathrm{Cl}_{2}\right)$. This compound displays in vivo and in vitro cytotoxic, genotoxic and proapoptotic effects towards cancer cells, as well as weaker toxicity than cisplatin in normal lymphocytes. ${ }^{19-24}$ The present study describes the synthesis, structural characterization and in vitro cytotoxic and proapoptotic activity of trans- $\mathrm{Pt}(3-\mathrm{af})_{2} \mathrm{Cl}_{2}$ against cancer cells and normal human peripheral blood lymphocytes; cisplatin was used as a reference compound.

\section{Results and discussion}

\section{General observations}

The novel platinum compound was synthesized according to Scheme 1 and subsequently characterized by elemental analysis, ESI-MS, IR and NMR spectroscopy; X-ray analysis of the structure was also performed. The anticancer activity was studied using various cancer cell lines and normal human lymphocytes.

\section{Crystal structure description}

The main aim of the X-ray crystallographic studies was to determine the molecular structure and coordination geometry of trans-Pt $(3-\mathrm{af})_{2} \mathrm{Cl}_{2}$. Particular emphasis was placed on identifying potential binding sites of the 3-aminoflavone ligand, nitrogen or oxygen atom, especially with respect to other previously-determined structures. ${ }^{25-27}$ Fig. 1 shows a displacement ellipsoid plot of the molecule with an atom-labeling scheme. The structure of the complex is composed of one platinum cation, two 3-aminoflavone ligands in their neutral form and two chloride anions.

In the crystal lattice, two nitrogen $\mathrm{N}(3)$ atoms of the 3-aminoflavone ligand and two chloride $\mathrm{Cl}(1)$ anions are bound to a central platinum(1) atom lying on crystallographic inversion in a slightly distorted planar square. This distortion of square planar coordination results from differences in the metal-ligand bond lengths. The bond distances around the $\mathrm{Pt}(1)$ atom and its neighboring $\mathrm{N}(3)$ and $\mathrm{Cl}(1)$ atoms, as well as respective valence angles are presented in Table 1. The length of the Pt-N bond, 2.064(5) $\AA$, is significantly longer than that for the other complexes with the same ligand, which are about $1.986(3) \AA$ for the $\mathrm{Cu}-\mathrm{N}$ bond ${ }^{25,26}$ and $1.910(4)$ for the $\mathrm{Ru}-\mathrm{N}$ bond. ${ }^{27}$ The plane, defined by $\mathrm{Pt}(1), \mathrm{N}(3), \mathrm{Cl}(1), \mathrm{N}(3)^{\#}, \mathrm{Cl}(1)^{\#}$ atoms (symmetry code \#: $-x,-y+1,-z+1$ ), is planar within

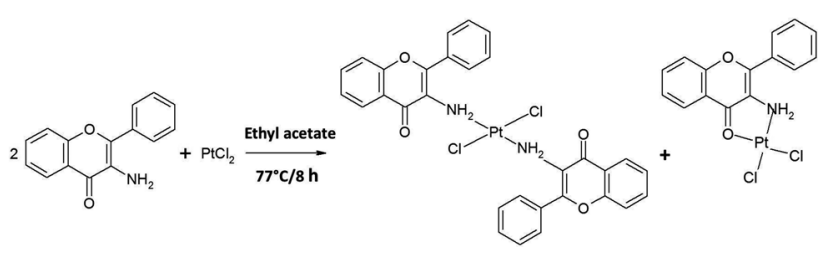

Scheme 1 Synthesis of trans- $\mathrm{Pt}(3-\mathrm{af})_{2} \mathrm{Cl}_{2}$ and $\mathrm{Pt}(3-\mathrm{af}) \mathrm{Cl}_{2}$ (see Experimental).

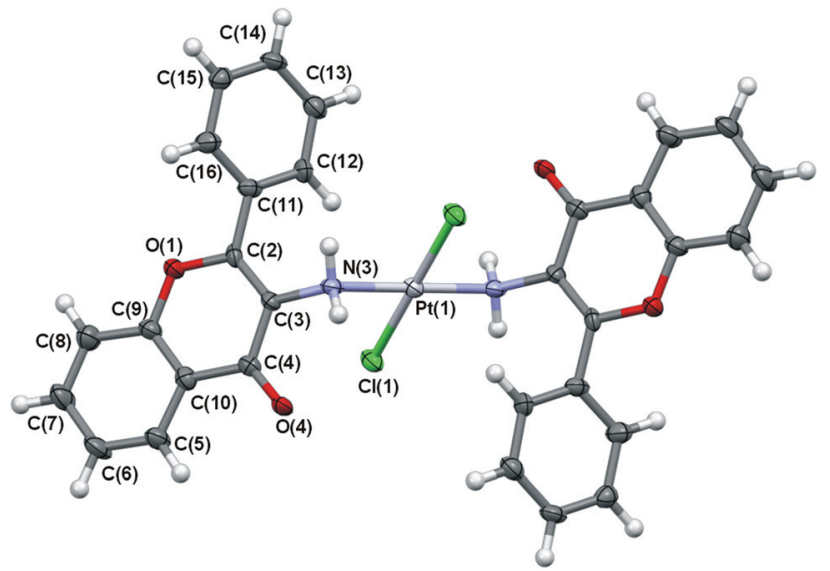

Fig. 1 A displacement ellipsoid plot of the complex molecule with a non- $\mathrm{H}$ atom labeling scheme. Unlabelled atoms are related by an inversion centre. Atomic displacement ellipsoids are drawn at a 50\% probability level. Selected bond lengths $[\AA \AA]$ and angles $\left[{ }^{\circ}\right]$ : $\mathrm{Pt}(1)-\mathrm{N}(3)$ 2.064(5), $\mathrm{Pt}(1)-\mathrm{Cl}(1)$ 2.298(1), $\quad \mathrm{N}(3)-\mathrm{Pt}(1)-\mathrm{Cl}(1)$ 92.7(1), $\quad \mathrm{C}(3)-\mathrm{N}(3)$ 1.443(7), $C(2)-C(3) 1.355(8), C(3)-C(4) 1.451(8)$.

Table 1 Summary of the $\mathrm{IC}_{50}$ values of trans- $\mathrm{Pt}(3-\mathrm{af})_{2} \mathrm{Cl}_{2}$ and cisplatin on tumour cells and lymphocytes

\begin{tabular}{lcc}
\hline & \multicolumn{2}{l}{$\mathrm{IC}_{50}(\mu \mathrm{M})$} \\
\cline { 2 - 3 } & $\operatorname{trans}$-Pt $(3-\mathrm{af})_{2} \mathrm{Cl}_{2}$ & Cisplatin \\
\hline L1210 & $6.6 \pm 0.7$ & $1.00 \pm 0.14$ \\
L1210R & $4.6 \pm 0.5(0.7)^{a}$ & $2.4 \pm 0.11(2.4)^{a}$ \\
HL-60 & $8.1 \pm 1$ & $2.1 \pm 0.2$ \\
HeLa & $8.3 \pm 0.7$ & $2.1 \pm 0.3$ \\
EJ & $16.3 \pm 0.3$ & $1.6 \pm 0.5$ \\
EJcisR & $14.2 \pm 1.5(0.87)^{a}$ & $11.7 \pm 1.5(7.3)^{a}$ \\
Lymphocytes & $9.3 \pm 2.1$ & $0.8 \pm 0.2$
\end{tabular}

${ }^{a}$ Resistance factor, defined as $\mathrm{IC}_{50}($ resistant $) / \mathrm{IC}_{50}$ (sensitive), is given in parenthesis.

experimental errors. The atoms of the same element occupy trans positions of the basal coordination plane.

The complex molecule consists of several planar fragments. Plane A is the central plane of the molecule described above, formed as a result of coordination, involving a central Pt(1) atom, two $\mathrm{N}(3)$ and two $\mathrm{Cl}(1)$ atoms. With regard to the 3-aminoflavone moiety, two other planes may be defined: plane $\mathrm{B}$ comprising condensed phenyl-pyrane rings $(\mathrm{O}(1), \mathrm{C}(2), \mathrm{C}(3)$, $\mathrm{C}(4), \mathrm{C}(5), \mathrm{C}(6), \mathrm{C}(7), \mathrm{C}(8), \mathrm{C}(9), \mathrm{C}(10)$ atoms) and plane $\mathrm{C}$ of the phenyl substituent $(\mathrm{C}(11), \mathrm{C}(12), \mathrm{C}(13), \mathrm{C}(14), \mathrm{C}(15), \mathrm{C}(16)$ atoms). The conformation of the benzopyrane moiety may be regarded as essentially planar, with a maximum deviation from the adequate least square plane B of $0.023(6) \AA$, observed for the $\mathrm{C}(4)$ atom. The coordination (A) and benzopyrane (B) planes are close to perpendicularity, with a dihedral angle equal to $78.1(2)^{\circ}$. The phenyl substituent (plane C) forms dihedral angles of $50.5(2)^{\circ}$ and $52.8(2)^{\circ}$ with planes A and B, respectively. The corresponding planes related by the inversion center are situated parallel to each other. Moreover $\mathrm{C}(5), \mathrm{C}(6)$, $\mathrm{C}(7), \mathrm{C}(8), \mathrm{C}(9), \mathrm{C}(10)$ phenyl rings of neighboring molecules 
are stacked in the crystal structure with interplanar distances 3.589(3) A and 3.551(3) A. This stacking is accompanied by respective ring slippage equal to 1.481(4) ̊̊ and 1.546(4) A.

With regard to the structure of the 3-aminoflavone ligand, the differentiation of $\mathrm{C}-\mathrm{C}$ bond lengths within the pyrane system is typical, ${ }^{28-32}$ varying from $1.355(8) \AA$ to $1.460(8) \AA$ for $\mathrm{C}(2)-\mathrm{C}(3)$ and $\mathrm{C}(4)-\mathrm{C}(10)$ bonds, respectively. Moreover, coordination to the $\mathrm{Pt}(1)$ cation increases the $\mathrm{C}(3)-\mathrm{N}(3)$ bond length by about $0.04 \AA$ in comparison with a free ligand $-1.396(2),{ }^{26}$ while the $\mathrm{C}(4)-\mathrm{O}(4)$ bond distance of $1.231(7) \AA$ is in line with a double bond. ${ }^{33}$

The crystal-packing arrangement is mainly directed by hydrogen bonding interactions. Conventional hydrogen bonds are formed between the nitrogen $\mathrm{N}(3)$ atom of an amine group and the carbonyl $\mathrm{O}(4)$ atom (symmetry: $-x+1,-y+1,-z+1$ ). Geometrical parameters typical for such an interaction are included in Table S1. $\uparrow$ The intermolecular distance $\mathrm{N}(3) \cdots \mathrm{O}(4)$ equal to $2.868(7) \AA$, and the angle $\mathrm{N}(3)-\mathrm{H}(3 \mathrm{~A}) \cdots \mathrm{O}(4)$ of $155.7^{\circ}$ are indicative of medium-strong hydrogen bonds. As a result of this intermolecular hydrogen bond a centrosymmetric $\mathrm{R}_{2}{ }^{2}(10)$ ring motif according to graph-set notation ${ }^{34}$ is closed. However, taking into account that one complex molecule is linked by four $\mathrm{N}-\mathrm{H} \cdots \mathrm{O}$ interactions, in two as a proton donor and in two as a proton acceptor, the hydrogen bonding network becomes more complicated. The obtained scheme of the $\mathrm{N}-\mathrm{H} \cdots \mathrm{O}$ hydrogen bonding network is shown in Fig. 2. Thus, $\mathrm{N}(3)-\mathrm{H}(3 \mathrm{~A}) \cdots \mathrm{O}(4)$ hydrogen bonds also connect molecules related by translation along the $a$-axis of the unit cell, forming a chain motif $\mathrm{C}(7)$. However, as only half the molecule occupies an asymmetric unit, molecules linked into a chain are also centrosymmetrically paired into the mentioned rings. Finally, the intermolecular hydrogen bond pattern can be described as an infinite chain of centrosymmetric rings, running along the [100] direction with respective graph set $\mathrm{C}(7)\left[\mathrm{R}_{2}^{2}(10)\right]$.

Another two hydrogen bonds, defined by a hydrogen... Sacceptor distance shorter than the sum of van der Waals radii, are formed between $\mathrm{C}-\mathrm{H}$ donors and a chloride anion $\mathrm{Cl}(1)$ or oxygen atom $\mathrm{O}(4)$. Relatively long intermolecular distances suggest that they may be classified as rather weak

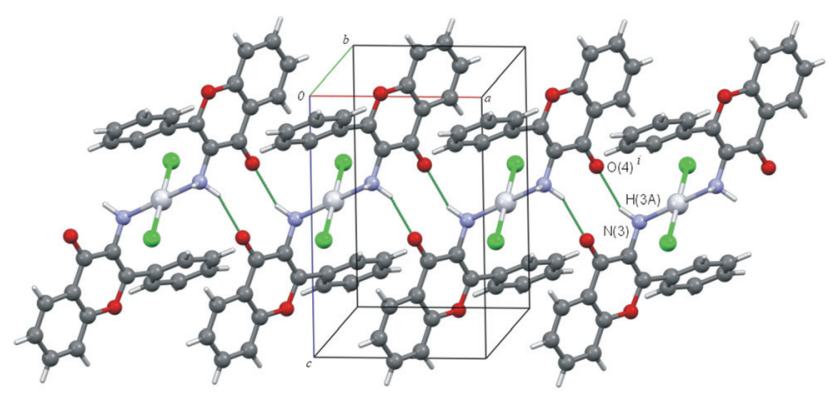

Fig. 2 The supramolecular chain of the ring motif of molecules linked by $\mathrm{N}(3)-\mathrm{H}(3 \mathrm{~A}) \ldots \mathrm{O}(4)$ intermolecular hydrogen bonds in a crystallographic [100] direction. $\mathrm{N}-\mathrm{H} \ldots \mathrm{O}$ hydrogen bonds are shown with dashed lines. Geometric parameters: $\mathrm{N}(3) \cdots \mathrm{O}(4) 2.868(6)[\AA]$ and $\mathrm{N}(3)-$ $\mathrm{H}(3 \mathrm{~A}) \cdots \mathrm{O}(4) 155.7\left[^{\circ}\right]$ and symmetry code $i:-x+1,-y+1,-z+1$. interactions. Details of these hydrogen bonds are given in Table S2.†

\section{Cytotoxicity evaluation (MTT assay)}

trans-Pt(3-af $)_{2} \mathrm{Cl}_{2}$ revealed significant cytotoxicity towards all tested cell lines with $\mathrm{IC}_{50}$ values in the 4.6-16.3 $\mu \mathrm{M}$ range (Table 1). TCAP was found to be slightly less cytotoxic to the tested cancer cell line than cisplatin. Furthermore, TCAP was also less toxic for normal lymphocytes in comparison with cisplatin, which is especially desirable for the prevention of potential drug side-effects. The concentrations causing 50\% inhibition of lymphocyte proliferation were $9.3 \mu \mathrm{M}$ for TCAP and 0.8 for cis-DDP.

For TCAP no significant differences were observed between L1210 and EJ cells and their cisplatin-resistant sublines: L1210R and EJcisR. Hence, TCAP has the ability to retain cytotoxic activity against cisplatin-resistant cell lines, which could be explained as alternative mechanisms of action. Additionally, TCAP demonstrated a slightly greater cytotoxic effect on cisplatin-resistant lines than sensitive sub-lines. This is an interesting finding, as cisplatin was 2- and 7-times less active toward L1210R and EJcisR cells, respectively. With respect to incubation time, our findings reveal no differences in the cytotoxicity of TCAP towards cancer cells when applied for $72 \mathrm{~h}$ and for shorter times of $24 \mathrm{~h}$ and $48 \mathrm{~h}$ (see Fig. S1†). Free 3-aminoflavone was not cytotoxic at concentration up to $100 \mu \mathrm{M} .{ }^{35}$ These results are very promising, as they indicate that TCAP has beneficial features for potential anticancer agents.

\section{Apoptosis evaluation}

Apoptotic pathways are important targets that should be considered in the design of potential anticancer agents. It is especially advantageous if the new compound triggers the death of cancer cells by apoptosis. Apoptosis is a tightly-regulated process characterized by several morphological and biochemical features, including changes in the kinetics of phosphatidylserine exposure on the outer leaflet of the plasma membrane, changes in mitochondrial membrane permeability leading to the release of apoptotic proteins, and activation of caspase and cleavage of nuclear DNA.

To better understand the nature of the promising cytotoxic activity demonstrated by TCAP, its effects at the cellular level, particularly, the mechanism of cell death, were subjected to further tests. Several different methods were used to compare the activities of trans-Pt(3-af $)_{2} \mathrm{Cl}_{2}$ and cisplatin in inducing apoptosis in model cancer cell lines.

\section{Measurement of mitochondrial transmembrane potential $\left(\Delta \Psi_{\mathbf{m}}\right)$}

One of the best-known aspects of mitochondrial involvement in apoptosis is the onset of multiple parameters of mitochondrial dysfunction including membrane depolarization. Flow cytometric analysis of transmembrane potential has been used to determine whether the trans- $\mathrm{Pt}(3-\mathrm{af})_{2} \mathrm{Cl}_{2}$ compound might directly target mitochondria in tumor cells to cause the 


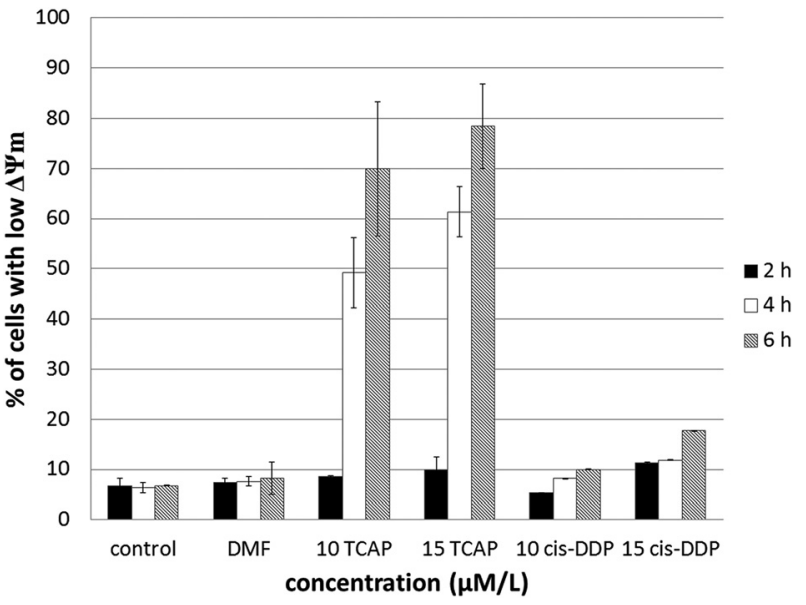

Fig. 3 Flow cytometric analysis of cells with low $\Delta \Psi_{\mathrm{m}}$. Percentage of apoptotic cells in $\mathrm{L} 1210$ cell culture following trans-Pt(3-af) $\mathrm{Cl}_{2}$ (TCAP) and cisplatin (cis-DDP) treatment after $2 \mathrm{~h}, 4 \mathrm{~h}$ and $6 \mathrm{~h}$ incubation. Results shown are representative data of at least three individual studies.

collapse of mitochondrial membrane potential $\left(\Delta \Psi_{\mathrm{m}}\right)$ which is linked to permeability by transition pore opening, leading to apoptosis. MitoTracker Red was used as a probe of $\Delta \Psi_{\mathrm{m}}$. The drop of $\Delta \Psi_{\mathrm{m}}$ was detected by flow cytometry as a decrease in red fluorescence of the dye in treated cells as compared to untreated cells. Fig. 3 shows the effects of TCAP and cisplatin on mitochondrial transmembrane potential in L1210 cells. The obtained results indicate that the complex induces a collapse of the mitochondrial membrane potential, as assessed by the dose- and time-dependent increase in the percentage of cells with depolarized mitochondria. Indeed, at a concentration of $15 \mu \mathrm{M}$ TCAP, about $75 \%$ of the cells were found to be affected after 6 hours. Interestingly, cisplatin was found to be ineffective under the same conditions, with no more than $15 \%$ of cells being detected as a collapse of $\Delta \Psi_{\mathrm{m}}$ positive, which suggests that it has a different target to TCAP.

\section{Caspase-3 activity}

The next set of tests was performed to determine whether a drop in mitochondrial membrane potential occurring at early stage of apoptosis precedes the caspase- 3 activation. Caspase-3 activation was chosen as an indicator of apoptosis induction, as different upstream pathways leading to apoptosis depend on it for final apoptotic execution.

Leukemia cells (L1210) were incubated with TCAP and cisplatin for 2, 4 and 6 hours to estimate the time needed to initiate the apoptosis process. The obtained results show that up to $40 \%$ of the cells undergo apoptosis after $4 \mathrm{~h}$ incubation with $10 \mu \mathrm{M}$ TCAP, while this number increases to $60 \%$ at $15 \mu \mathrm{M}$ TCAP. Furthermore, when incubation was prolonged to $6 \mathrm{~h}, 70 \%$ to $75 \%$ of the treated cells were affected. Interestingly, cisplatin was found to be ineffective under the same conditions, with no more than $10 \%$ being detectable as a caspase3 positive at $10 \mu \mathrm{M}$ and $15 \% 15 \mu \mathrm{M}$. The cells with active caspase-3 were confirmed to have significant involvement in the caspase-dependent apoptotic pathway. Furthermore, Fig. 3

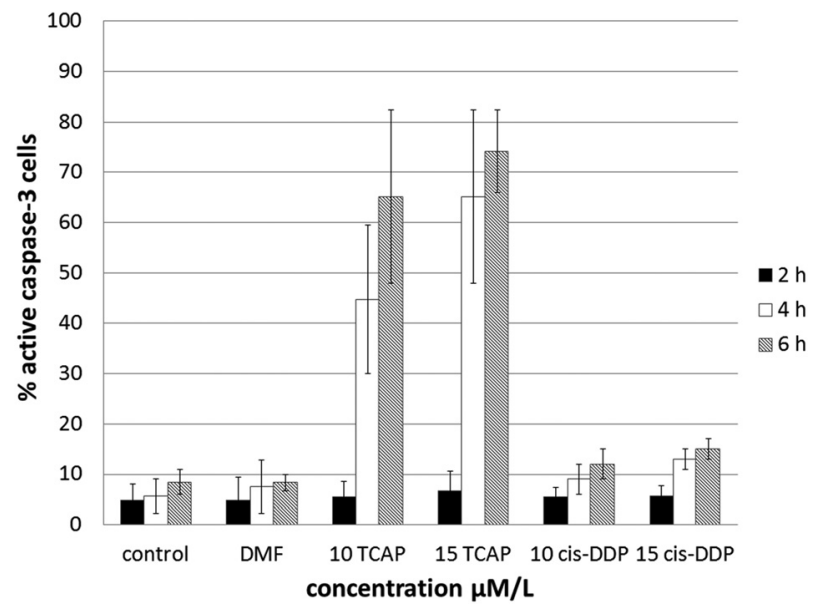

Fig. 4 Flow cytometric analysis of active-caspase-3 cells. Percentage of apoptotic cells in $\mathrm{L} 1210$ cell culture following trans-Pt(3-af) ${ }_{2} \mathrm{Cl}_{2}$ (TCAP) and cisplatin (cis-DDP) treatment after $2 \mathrm{~h}, 4 \mathrm{~h}$ and $6 \mathrm{~h}$ incubation. Results shown are representative data of at least three individual studies.

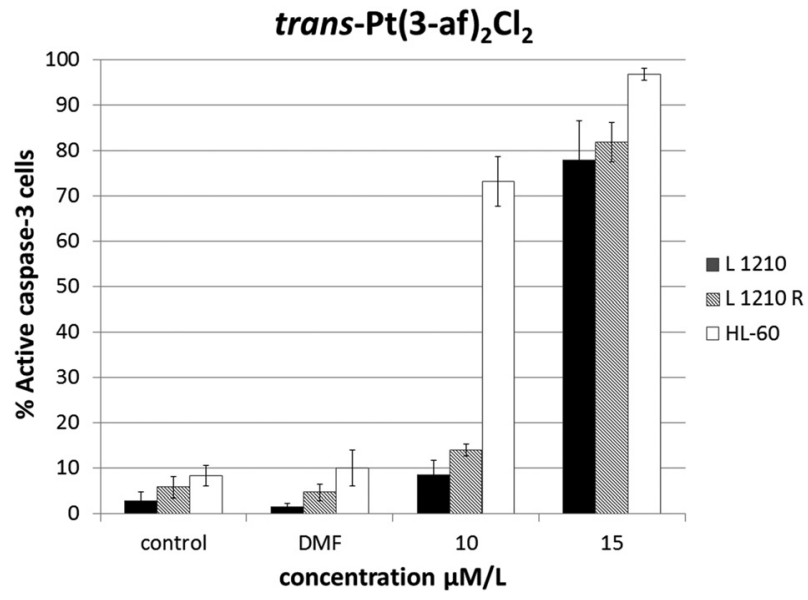

Fig. 5 Flow cytometric analysis of active-caspase-3 cells. Percentage of apoptotic cells in L1210, L1210R and HL-60 cell culture following trans- $\mathrm{Pt}(3-\mathrm{af})_{2} \mathrm{Cl}_{2}$ treatment after $4 \mathrm{~h}$ incubation and $20 \mathrm{~h}$ postincubation. Results shown are representative data of at least three individual studies.

and 4 indicate that the collapse of mitochondrial transmembrane potential $\left(\Delta \Psi_{\mathrm{m}}\right)$ induced by TCAP is strictly correlated with the triggering of the intrinsic proapoptotic pathway with the effector caspase-3.

As the minimum time needed to induce apoptosis was found to be $4 \mathrm{~h}$, the next stage of the study was incubation of the cells with tested compounds for $4 \mathrm{~h}$ and then postincubation in fresh medium for 20 hours to evaluate whether the initiated apoptosis process will continue despite the lack of drugs. The results are shown in Fig. 5 and 6. All three leukemia cell lines treated with TCAP showed increasing degrees of caspase-3 positivity in a dose-dependent manner, indicating that the cells were undergoing apoptosis. It was observed that 


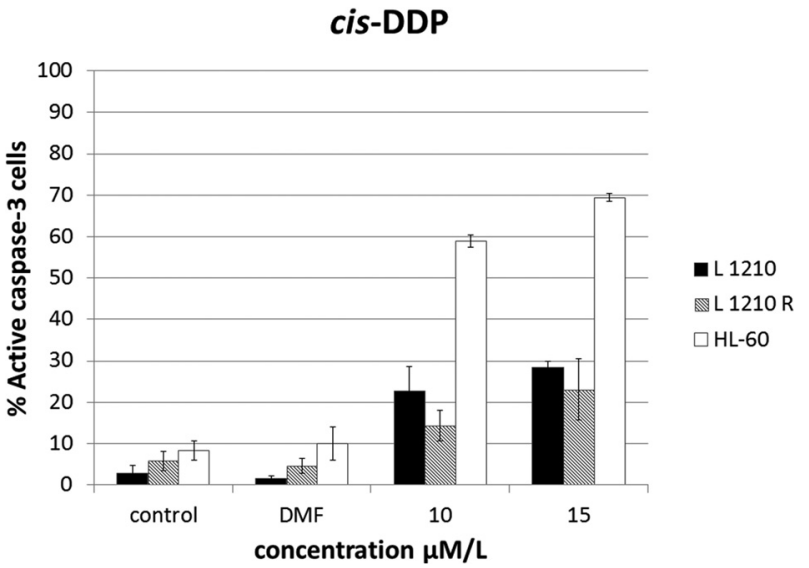

Fig. 6 Flow cytometric analysis of active-caspase- 3 cells. Percentage of apoptotic cells in L1210, L1210R and HL-60 cell culture following cisplatin (cis-DDP) treatment after $4 \mathrm{~h}$ incubation and $20 \mathrm{~h}$ postincubation. Results shown are representative data of at least three individual studies.

TCAP induced apoptosis as much as three times more effectively (L1210R) than cisplatin, with the population of the apoptotic cells ranging between 80 and $90 \%$ at its highest concentration.

\section{Annexin-V staining}

Exposure of phosphatidylserine (PS) on the external surface of the cell membrane has been shown to occur in the early stages of apoptotic cell death and can be detected using Annexin-V. Leukemia cells (L1210, L1210R and HL-60) were treated with TCAP and cisplatin for 4 hours, postincubated in fresh medium for 20 hours at concentrations of $10 \mu \mathrm{M}$ and $15 \mu \mathrm{M}$, and then collected for Annexin-V-FITC/propidium iodide staining.

The assays showed that the studied compound induced apoptosis of the majority of cells. All the three leukemia cell lines treated with TCAP showed increasing degrees of Annexin- $\mathrm{V}$ positivity in a dose-dependent manner, indicating that the cells were undergoing apoptosis. This assay confirmed that the apoptosis process is continuous despite the removal of the drug (Fig. 7 and 8).

\section{Apoptotic DNA fragmentation}

To check whether DNA degradation may be a result of the apoptosis process, gel electrophoresis of DNA extracted from the cells was assessed. After $4 \mathrm{~h}$ drug exposure and $20 \mathrm{~h}$ or $44 \mathrm{~h}$ post-drug incubation, gel electrophoresis was performed with DNA extracted from the cells treated with the drug (Fig. 9). Distinct DNA laddering was observed when cells were treated with TCAP at concentrations equivalent to $2 \times \mathrm{IC}_{50}$ (lines 3,10$)$ and $3 \times \mathrm{IC}_{50}$ (lines 3,11 ). DNA laddering was much weaker, in fact it was barely visible when cells were treated with cisplatin at equivalent doses of $2 \times \mathrm{IC}_{50}$ and $3 \times \mathrm{IC}_{50}$. When postincubation was prolonged up to $40 \mathrm{~h}$, both TCAP and cisplatin demonstrated a clearly evident DNA laddering pattern: lines 10, 11 and 12,13, respectively. These results may suggest

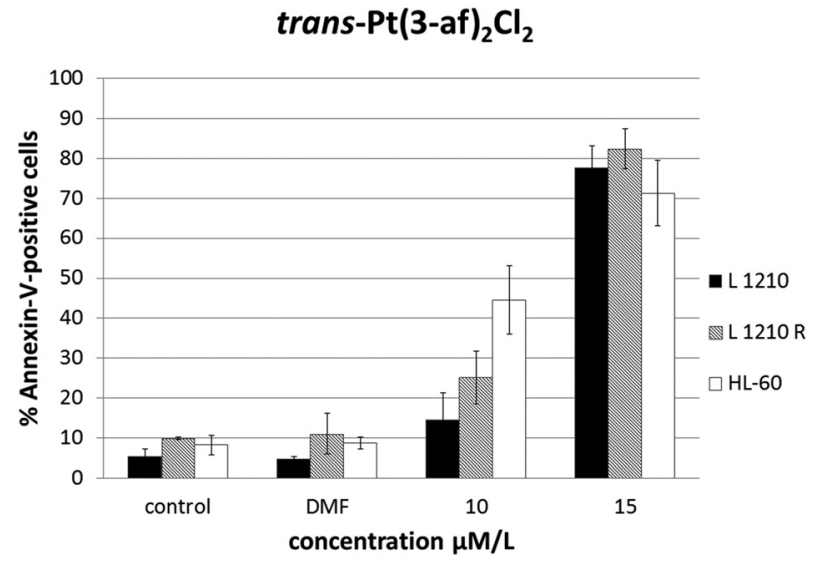

Fig. 7 Flow cytometric analysis of Annexin-V-positive cells. Percentage of apoptotic cells in L1210, L1210R and HL-60 cell culture following trans $-\mathrm{PtCl}_{2}(\text { af })_{2}$ treatment after $4 \mathrm{~h}$ incubation and $20 \mathrm{~h}$ postincubation. Results shown are representative data of at least three individual studies.

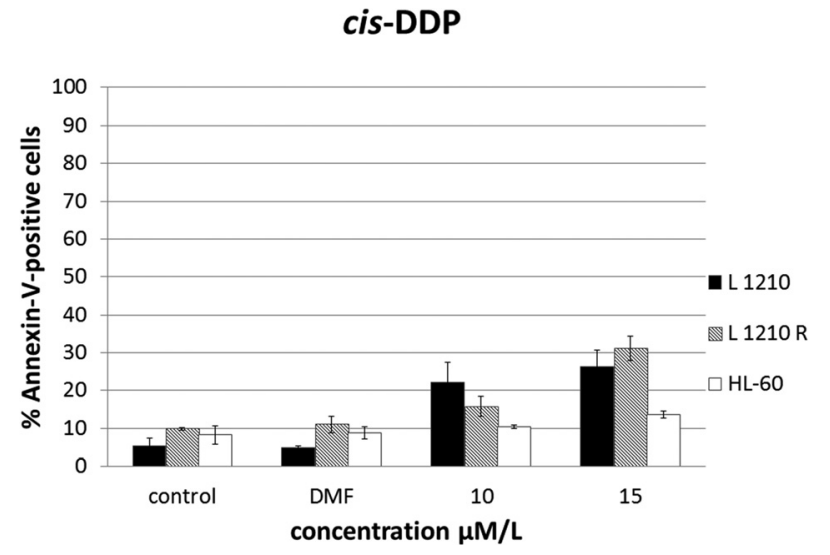

Fig. 8 Flow cytometric analysis of Annexin-V-positive cells. Percentage of apoptotic cells in L1210, L1210R and HL-60 cell culture following cisplatin (cis-DDP) treatment after $4 \mathrm{~h}$ incubation and $20 \mathrm{~h}$ postincubation. Results shown are representative data of at least three individual studies.

that the detected DNA degradation caused by TCAP indicates the presence of apoptosis. For both tested compounds, DNA appeared as characteristic ladder-like fragments, which is the biochemical hallmark of apoptosis. The results were compared to the negative control (untreated cells) where no laddering pattern or smear was seen.

\section{Acridine orange and ethidium bromide staining (AO/EB)}

Acridine orange and ethidium bromide staining was used to compare proapoptotic potential of the tested trans-platinum(II) compound with that of cisplatin towards both the sensitive and the resistant lines of mouse leukemia cells. Fluorescent dyes used in the assay bind DNA in the cells and enable apoptotic, necrotic and normal cells to be distinguished. Morphological cellular changes that are characteristic hallmarks of programmed cell death included abnormal shape and volume, loss of cell membrane asymmetry, nuclear and chromatin condensation, and blebbing of the plasma membranes (see 


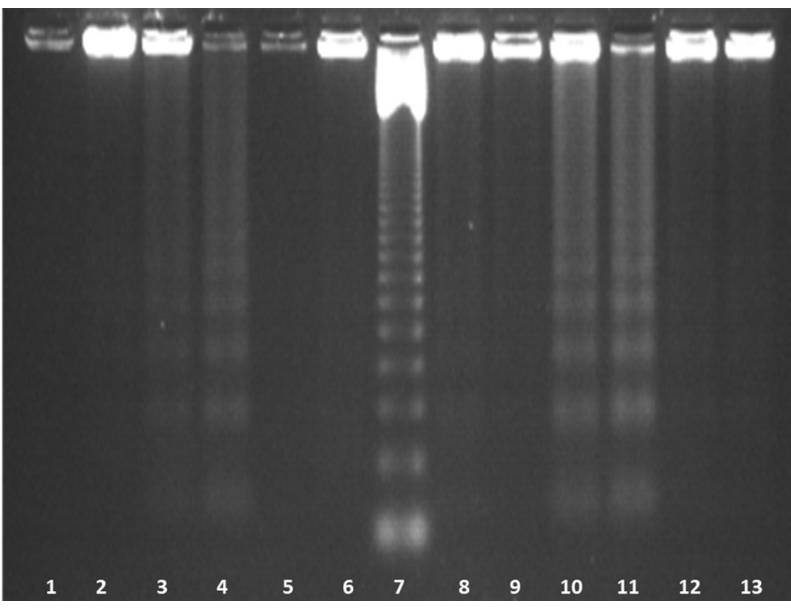

Fig. 9 Agarose gel electrophoresis of DNA from treated cells. L1210R cells were exposed to drugs for $4 \mathrm{~h}$ and then postincubated in a drugfree medium for the following $20 \mathrm{~h}$ (tracks 1-6) or $44 \mathrm{~h}$ (tracks 8-13). DNA was isolated from the cells and run on a $1.8 \%$ agarose gel as described in the Experimental section. Tracks: 1, control (untreated); 2, control + DMF; 3, TCAP $\left(2 \times \mathrm{IC}_{50}\right) ; 4$, TCAP $(3 \times \mathrm{IC} 50) ; 5$, cisplatin $\left(2 \times I C_{50}\right) ; 6$, cisplatin $\left(3 \times I C_{50}\right) ; 7$, marker (DNA ladder $\left.123 \mathrm{bp}\right) ; 8$, control (untreated); 9, control + DMF; 10, TCAP $\left(2 \times I C_{50}\right) ; 11$, TCAP $\left(3 \times I C_{50}\right) ; 12$, cisplatin $\left(2 \times \mathrm{IC}_{50}\right)$; 13 , cisplatin $\left(3 \times \mathrm{IC}_{50}\right)$.

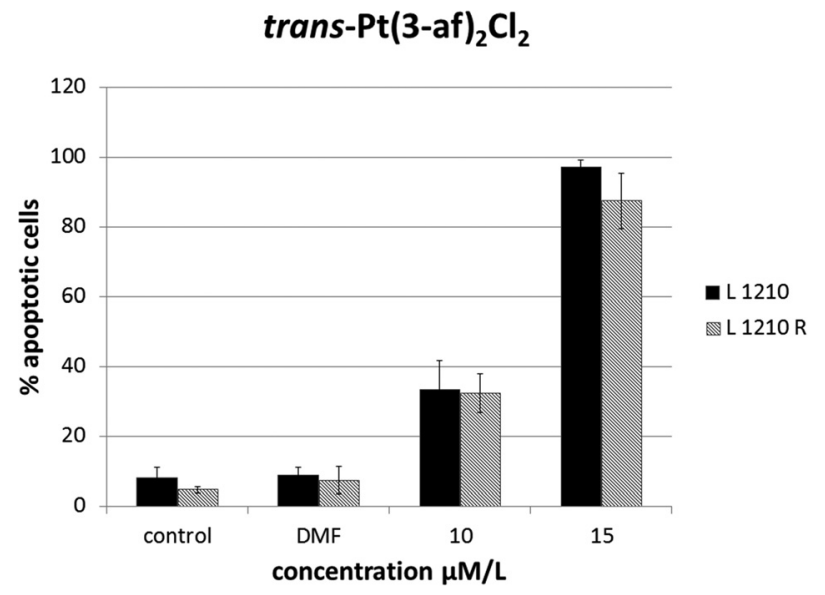

Fig. 10 Fluorescence microscopy analysis. Percentage of apoptotic cells in L1210 and L1210R cell culture treated with trans-Pt(3-af $)_{2} \mathrm{Cl}_{2}$ for $4 \mathrm{~h}$ and postincubated for $20 \mathrm{~h}$ evaluated by acridine orange/ethidium bromide nuclear staining. Results shown are representative data of at least three individual studies.

Fig. S2 $\dagger$ ). The results after $4 \mathrm{~h}$ of incubation and $20 \mathrm{~h}$ postincubation in fresh medium are shown in Fig. 10 and 11.

Our results reveal that trans-Pt(3-af $)_{2} \mathrm{Cl}_{2}$ induce apoptosis more effectively than cisplatin. At $10 \mu \mathrm{M}$ TCAP causes apoptosis induction in about $30 \%$ of the cells, while cisplatin was found to cause apoptosis in about $20 \%$. Furthermore $15 \mu \mathrm{M}$ of the TCAP compound is sufficient to induce apoptosis in the majority of cells of both lines; a proapoptotic effect is observable in about $90 \%$ of cells. This experiment shows that the proapoptotic activity of compound 2 is 2 - to 4 -times higher than that of cisplatin. Therefore, our findings indicate that TCAP

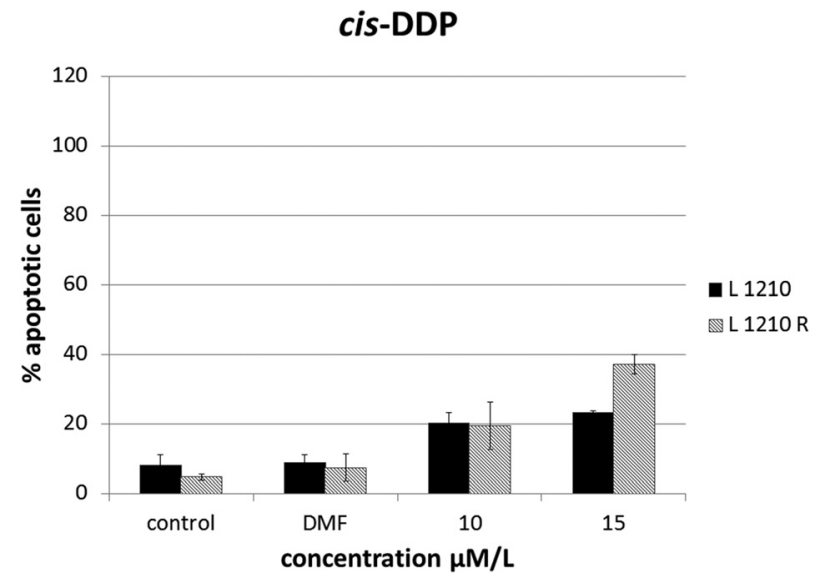

Fig. 11 Fluorescence microscopy analysis. Percentage of apoptotic cells in L1210 and L1210R cell culture treated with cisplatin (cis-DDP) for $4 \mathrm{~h}$ and postincubated for $20 \mathrm{~h}$ evaluated by acridine orange/ethidium bromide nuclear staining. Results shown are representative data of at least three individual studies.

inhibits tumour cell proliferation and causes cytotoxicity via programmed cell death.

\section{Experimental}

\section{Chemicals}

3-Hydroxyiminoflavanone, 3-aminoflavone, and the two Pt(II) complexes were synthesized as described below. Other reagents were purchased from Sigma-Aldrich, Alfa Aesar and POCh (Poland).

\section{Synthesis of 3-aminoflavone (3-af)}

The synthesis followed the procedure described elsewhere. ${ }^{28}$

Synthesis and characterization of trans- $\mathrm{Pt}(3-\mathrm{af})_{2} \mathrm{Cl}_{2}$

Synthesis of trans-Pt(3-af $)_{2} \mathbf{C l}_{2}$. To the solution of 3-aminoflavone (3-af) $(0.273 \mathrm{~g}, 1 \mathrm{mmol})$ in dry ethyl acetate $(200 \mathrm{ml})$ platinum chloride(II) $(0.133 \mathrm{~g}, 0.5 \mathrm{mmol})$ was added. The mixture was stirred under reflux for $6 \mathrm{~h}$ with protection from light. The precipitate was filtered off, washed with dry ethyl acetate and air dried. A yellow powder was obtained with a yield of $0.223 \mathrm{~g}(61 \%)\left(\mathrm{Pt}(3-\mathrm{af}) \mathrm{Cl}_{2}\right)$. The filtrate was concentrated and left to evaporate slowly to allow the complex to crystallize. The obtained yellow crystals, suitable for X-ray measurement, were then filtered and dried: the yield was $0.066 \mathrm{~g}$ (18\%); M.p. $247-252{ }^{\circ} \mathrm{C}$ (trans-Pt(3-af) $)_{2} \mathrm{Cl}_{2}$; TCAP). The complex is soluble in DMSO, DMF; moderately soluble in methanol, 2-propanol and acetonitrile; insoluble in water, diethyl ether and acetone.

The structure of $\mathrm{Pt}(3-\mathrm{af}) \mathrm{Cl}_{2}$ was determined by elemental analysis, IR and FAB-MS spectroscopy but further X-ray experiment is still required.

The structure of trans-Pt(3-af) $)_{2} \mathrm{Cl}_{2}$ was determined by elemental analysis, IR, ${ }^{1} \mathrm{H} \mathrm{NMR},{ }^{13} \mathrm{C}$ NMR spectroscopy and 
electrospray mass spectrometry. $\mathrm{C}_{30} \mathrm{H}_{22} \mathrm{Cl}_{2} \mathrm{~N}_{2} \mathrm{O}_{4} \mathrm{Pt}$ (740.49 $\mathrm{g} \mathrm{mol}^{-1}$ ): calculated. C 48.66; H 2.99; N 3.78; found: C 48.63; H 2.56; $\mathrm{N}$ 3.63(\%). Selected IR data $\left(\mathrm{KBr}, \mathrm{cm}^{-1}\right)$ : 3265.4, 3119.1, $3072.9\left(\mathrm{NH}_{2}\right), 1633.5$ (CO), $1549.2\left(\mathrm{CNH}_{2}\right), 489.0(\mathrm{PtN}) .{ }^{1} \mathrm{H}$ $\mathrm{NMR}_{\text {DMF-d }}(\delta, \mathrm{ppm}): 6.40\left(\mathrm{~s}, 2 \mathrm{H}, \mathrm{NH}_{2}\right), 7.58-7.61(1 \mathrm{H}, \mathrm{m})$, 7.72-7.76 (3H, m), 7.88-7.92 (1H, m) 8.04 (1H, dd), 8.54-8.57 $(2 \mathrm{H}, \mathrm{m})$ (Fig. S3†). ${ }^{13} \mathrm{C} \mathrm{NMR}, \mathrm{DMF}-\mathrm{d}_{7}(\delta, \mathrm{ppm}): 172.9,156.11$, 154.71 ; 134.85, 131.56, 131.32, 129.48, 129.06, 125.81, 125.72, 125.23, 121.45, 118.87 (Fig. S4†). ESI $^{+}$-MS (methanol) m/z: 763 $\left[\mathrm{Pt}(3-\mathrm{af})_{2} \mathrm{Cl}_{2}+\mathrm{Na}\right]^{+}, 669\left[\mathrm{Pt}(3-\mathrm{af})_{2}\right]^{+} 238(3-\mathrm{af})^{+}$. Melting point was determined with Böetius apparatus. Microanalyses of $\mathrm{C}, \mathrm{H}$ and $\mathrm{N}$ were performed with a Perkin Elmer 2400 analyzer. ${ }^{1} \mathrm{H}$ NMR and ${ }^{13} \mathrm{C}$ NMR experiments were carried out on a Bruker Avance III (500 MHz) spectrometer using DMF-d $\mathrm{d}_{7}$ as a solvent. IR spectra were carried out on an ATI Mattson Infinity Series FTIR $^{\mathrm{TM}}$ spectrometer using $\mathrm{KBr}$ pellets. Electrospray ionization-mass spectra (ESI-MS) were obtained in positive ion mode on a Varian 500-MS LC ion trap using methanol as the solvent.

\section{$\mathrm{X}$-ray structure determination and refinement}

A representative crystal of a suitable size was selected and mounted on a fiber loop and used for X-ray measurements. $\mathrm{X}$-ray data were collected at low temperature on a Stoe IPDS diffractometer ${ }^{36}$ with a monochromated Mo K $\alpha$ X-ray source. Data reduction was performed with the Stoe IPDS software which added Lorentz and polarization corrections. The crystal structure was solved by direct methods using SHELXS-86 ${ }^{37}$ and refined by the full-matrix least squares method using SHELXL- $97^{37}$ (both programs implemented in WinGX ${ }^{38}$ ). Refinement was carried out on $F^{2}$ by full-matrix least-squares procedures with minimized function $\sum \mathrm{w}\left(F_{\mathrm{o}}{ }^{2}-{F_{\mathrm{c}}}^{2}\right)^{2}$. All nonhydrogen atoms were refined with anisotropic displacement parameters. Hydrogen atoms of the phenyl rings were introduced in calculated positions with idealized geometry while amine hydrogen atoms were located on a difference Fourier map. In the last step of the refinement all the hydrogen atoms were constrained to ride on their parent atoms using a rigid body model with isotropic displacement parameters equal to $1.2 U_{\text {eq }}$ of appropriate $\mathrm{N}$ or $\mathrm{C}$ atom. A summary of the crystallographic data is given in Table 1 . The molecular geometry was calculated by PARST ${ }^{39}$ and Platon. ${ }^{40}$ Selected bond distances and angles are summarized in Table 2. Mercury version $2.4^{41}$ was used to present the intermolecular interaction network.

The coordinates and displacement parameters of the atoms are deposited with Cambridge Crystallographic Data Centre. CCDC 811964 number contains the supplementary crystallographic data for this paper.

\section{Cell cultures}

The in vitro anticancer chemotherapeutic potential of the platinum(II) complex was determined using murine (L1210, L1210R) and human (HL-60, HeLa, EJ, EJcisR) cancer cell lines and human lymphocytes. The cells were cultured in RPMI (Biological Industries) medium supplemented with 10\% foetal bovine serum (Biological Industries) and gentamycin (Biological Industries, $50 \mu \mathrm{g} \mathrm{ml} \mathrm{m}^{-1}$ ) in an atmosphere of $5 \% \mathrm{CO}_{2}$.
Table 2 Crystal data and structure refinement details

\begin{tabular}{ll}
\hline Crystal data & \\
\hline Formula & $\mathrm{C}_{30} \mathrm{H}_{22} \mathrm{Cl}_{2} \mathrm{~N}_{2} \mathrm{O}_{4} \mathrm{Pt}$ \\
Formula weight & 740.49 \\
Crystal system, space group & Triclinic, $P \overline{1}$ \\
Unit cell dimensions & $a=6.9226(4) \AA$ \\
& $b=9.2809(8) \AA$ \\
& $c=11.0038(9) \AA$ \\
& $\alpha=85.511(7)^{\circ}$ \\
& $\beta=87.997(6)^{\circ}$ \\
$V$ & $\gamma=77.091(7)^{\circ}$ \\
$Z, \mathrm{~d}_{x}$ & $686.88(9) \AA^{3}$ \\
$F(000)$ & $1,1.790 \mathrm{~g} \mathrm{~cm}^{-3}$ \\
Crystal size & 360 \\
Data collection & $0.10 \times 0.08 \times 0.05 \mathrm{~mm}$ \\
Temperature & \\
Radiation type, wavelength & $123 \mathrm{~K}$ \\
$\theta$ Range for data collection & $\mathrm{Cu} \mathrm{K \alpha}, 1.54178 \AA$ \\
Limiting indices & 4.03 to $62.45^{\circ}$ \\
& $-7 \leq h \leq 7$ \\
Reflections collected/unique & $-10 \leq k \leq 10$ \\
Completeness & $0 \leq l \leq 12$ \\
Refinement & $6975 / 2143\left[R_{(\mathrm{int})}=0.0461\right]$ \\
Refinement method & $98.2 \%$ \\
Data/restraints/parameters & \\
Goodness-of-fit on $F^{2}$ & Full-matrix least-squares on $F^{2}$ \\
Final $R$ indices $[I>2 \sigma(I)]$ & $2143 / 0 / 178$ \\
$R$ indices (all data) & 1.144 \\
Largest diff. peak and hole & $R_{1}=0.0309, \mathrm{w} R_{2}=0.0742$ \\
& $R_{1}=0.0347, \mathrm{w} R_{2}=0.0811$ \\
& 1.315 and $-1.783 \mathrm{e} \AA^{-3}$ \\
&
\end{tabular}

Cisplatin and TCAP for the assays were dissolved in DMF, with the DMF concentration in the cell incubation medium being $0.2 \%$.

Lymphocytes were isolated from peripheral blood of healthy donors, purchased from the Regional Blood Bank of Lodz, Poland with the approval of the Local Ethical Committee. Blood was collected in Monovette ${ }^{\mathrm{TM}}$ tubes with sodium citrate and processed within $3 \mathrm{~h}$. Centrifugation was carried out in a density gradient using Histopaque-1077 (Sigma). Lymphocytes were cultured in RPMI 1640 medium supplemented with $10 \%$ foetal bovine serum (Biological Industries), phytohemagglutinin-M (Biological Industries) and gentamycin (Biological Industries) in an atmosphere of $5 \% \mathrm{CO}_{2}$.

\section{MTT assay}

Each compound was tested for its cytotoxic activity in vitro against the cells of six cancer cell lines: HL-60 (human promyelocytic leukemia cell line), EJ (bladder cancer cell line), EJcisR (bladder cancer cell line resistant to cisplatin), HeLa (cervical cancer cell line), L1210 (mouse leukemia cell line) and L1210R (mouse leukemia cell line resistant to cisplatin). Human lymphocytes were used to assess the toxicity of the tested compounds towards normal cells. The cytotoxicity of trans-Pt(3-af $)_{2} \mathrm{Cl}_{2}$ was evaluated using the MTT assay, a colorimetric method based on the measurement of energetic cell metabolism (succinate dehydrogenase activity). The results of cytotoxic activity in vitro are expressed as $\mathrm{IC}_{50}$ values, i.e. the concentration of compound in $\mu \mathrm{M}$ needed to inhibit $50 \%$ of 
tumor cell growth as compared to control untreated cells. Cisplatin was used as a reference compound.

In this assay, yellow MTT (3-(4,5-dimethylthiazol-2-yl)-2,5diphenyltetrazolium bromide) is reduced to purple formazan in the mitochondria of living cells and the amount of produced formazan is measured colorimetrically. The cells were seeded in triplicates on 24 -well plates $\left(1.5 \times 10^{3}\right.$ cells per $1 \mathrm{ml}$ of medium for L1210 and L1210R; $2 \times 10^{4}$ per $\mathrm{ml}$ for EJ; $5 \times$ $10^{4}$ per $\mathrm{ml}$ for EJ-CPR; $1 \times 10^{4}$ per $\mathrm{ml}$ for HeLa; $1 \times 10^{4}$ per $\mathrm{ml}$ for HL-60) and left for $24 \mathrm{~h}$. The cells were then treated with the tested compounds dissolved in DMF ( $N, N$-dimethylformamide; concentration of DMF in cell cultures was $0.2 \%$ ). After a $72 \mathrm{~h}$ incubation at $37^{\circ} \mathrm{C}, 0.1 \mathrm{ml}$ of MTT solution $\left(5 \mathrm{mg} \mathrm{ml}^{-1}\right.$ in PBS) was added to each well and the plates were incubated for a further $2-3 \mathrm{~h}$ ( $4 \mathrm{~h}$ for lymphocytes). After removing the medium, the purple formazan precipitate was dissolved in DMSO and the absorbance was measured at $540 \mathrm{~nm}$ using an Ultrospec III UV/VIS spectrophotometer. Cytotoxic activity was expressed as percentage of the cellular growth inhibition in culture treated with complex compounds assuming the control, treated with DMF as $100 \%$. The results are presented as means of at least three independent experiments.

\section{Acridine orange and ethidium bromide staining (AO/EB)}

The murine leukemia cells (L1210, L1210R) were seeded on the tested tubes $\left(5 \times 10^{4}\right.$ cells per $1 \mathrm{ml}$ of medium). The next day the tested compounds were added and the tubes were incubated at $37{ }^{\circ} \mathrm{C}$ for $4 \mathrm{~h}$, before being incubated in fresh medium for another $20 \mathrm{~h}$. After the times indicated below, the cells were collected and centrifuged $\left(10 \mathrm{~min} / 1500 \mathrm{rpm} / 23^{\circ} \mathrm{C}\right)$. The cell pellets were suspended in $0.1 \mathrm{ml}$ of medium with $0.025 \mathrm{ml}$ of the staining mixture (acridine orange and

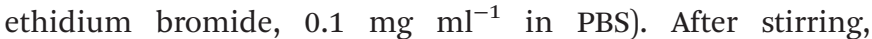
the cells were placed on slides and observed under a fluorescence microscope $\left(\chi_{\mathrm{ex}}=480-550 \mathrm{~nm}\right)$. At least 200 cells from each slide were counted, and the percentage of apoptotic cells was calculated on the basis of cellular morphological features. The results are shown as the mean of the three independent experiments.

\section{Genomic DNA electrophoresis (DNA ladder)}

This assay was used to detect DNA degradation resulting from apoptosis. The cells were treated with the tested compounds for $4 \mathrm{~h}$ at $37{ }^{\circ} \mathrm{C}$ in the growth medium. Following this, they were lysed on polycarbonate filters with $5 \mathrm{ml}$ of $2 \%$ sodium dodecyl sulphate dissolved in 0.01 M EDTA $(\mathrm{pH}=10)$.

L1210R cells were treated with TCAP and cisplatin, collected by centrifugation and fixed in $70 \%$ ethanol. The cells were centrifuged at $1500 \mathrm{rpm}$ for $5 \mathrm{~min}$ to remove the ethanol. The cell pellets were resuspended in $0.5 \mathrm{ml}$ of $\mathrm{pH}$ buffer $(45 \mathrm{mM}$ trisphosphate-borate, $1 \mathrm{mM}$ EDTA, 0.25\% Nonidet) and digested by DNase-free RNase A (Sigma, USA, $1 \mathrm{mg} \mathrm{mL}^{-1}$ ) for $30 \mathrm{~min}$ at $37{ }^{\circ} \mathrm{C}$ and later by proteinase $\mathrm{K}\left(1 \mathrm{mg} \mathrm{ml}{ }^{-1}, 30 \mathrm{~min}\right.$ at $\left.37^{\circ} \mathrm{C}\right)$. After digestion, $0.1 \mathrm{ml}$ of loading buffer $(0.25 \%$ bromophenol blue, $30 \%$ glycerol) was added and $70 \mu \mathrm{L}$ of DNA solutions were applied on the $1.8 \%$ agarose gel containing $0.5 \mu \mathrm{g} \mathrm{ml} \mathrm{m}^{-1}$ of ethidium bromide. Electrophoresis was performed at $1.2 \mathrm{~V}$ $\mathrm{cm}^{-1}$ for $17 \mathrm{~h}$. The DNA in gels was visualized under UV light and photographed using Ilford FP4 negative film.

\section{Activation of caspase- 3 measurement}

The main effectors of apoptosis are proteases belonging to the caspase family. Caspases represent key mediators in the initiation and execution of apoptosis. Active caspase-3 was detected using FITC conjugated rabbit antibody against active caspase-3 (BD Pharmingen).

Briefly, cells were seeded into test tubes and treated with appropriate concentrations of TCAP and cisplatin. After incubation, the cells were recovered and washed twice with phosphate-buffered saline (PBS), before being fixed and permeabilized using Cytofix/Cytoperm ${ }^{\mathrm{TM}}$ (BD Pharmingen) solution (20 $\mathrm{min}$, on ice), washed twice and resuspended in the Perm/Wash ${ }^{\mathrm{TM}}$ buffer (BD Pharmingen, San Diego, CA, USA). The antibody was added to $10 \mu \mathrm{l}$ per $100 \mu \mathrm{l}$ of cell suspension (30 min incubation, RT). The fluorescence was measured directly after staining and washing with Perm/Wash ${ }^{\mathrm{TM}}$ buffer by flow cytometry (FL1, green fluorescence filter).

\section{Annexin-V/PI propidium iodide assay}

The apoptotic cells were identified by flow cytometry using the Annexin-V/FITC (BD Pharmingen ${ }^{\mathrm{TM}}$ ) assay according to the manufacturer's instructions.

For detection of apoptosis and necrosis, FITC-labeled Annexin-V combined with PI was used to mark the presence of phosphatidylserine (PS), which is displayed during apoptosis at the cell surface. PI only stains the nuclei of damaged cells with permeable plasma membranes.

Briefly, the cells were incubated with TCAP and cisplatin for $4 \mathrm{~h}$ and then incubated in fresh medium for $20 \mathrm{~h}$. After incubation the cells were washed twice with cold PBS and then resuspended in $100 \mu \mathrm{L}$ of binding buffer, containing $2 \mu \mathrm{L}$ of FITC conjugated Annexin-V and $10 \mu \mathrm{g} \mathrm{ml} \mathrm{m}^{-1}$ of PI (BectonDickinson, San Jose, CA, USA). Then, the preparations were incubated at room temperature, protected from light, for 15 min. Fluorescence was measured immediately after staining by flow cytometry using FL1 (green, Annexin-V) and FL3 (red, PI) standard fluorescent filters.

\section{Collapse of mitochondrial transmembrane potential $\left(\Delta \Psi_{\mathrm{m}}\right)$ assessment}

The dissipation (collapse) of mitochondrial transmembrane potential $\left(\Delta \Psi_{\mathrm{m}}\right)$ occurs early during apoptosis and is often considered as a marker of apoptosis activated by the mitochondrial pathway. MitoTracker Red dye was used as a probe for $\Delta \Psi_{\mathrm{m}}$, which accumulates in the active mitochondria of living cells: $50 \mathrm{nM}, 20 \mathrm{~min}$ incubation, RT. The reduction of $\Delta \Psi_{\mathrm{m}}$ was detected by flow cytometry as a decrease in red fluorescence of the dye in treated cells as compared to untreated cells. 


\section{Conclusions}

The anticancer activity and molecular mechanisms of action of trans-platinum complexes have been extensively studied in the last 20 years. Continuing our study on metal complexes of 3-aminoflavone, this study describes the synthesis, characterization and in vitro activity of trans-bis-(3-aminoflavone)dichloridoplatinum(II) (trans-Pt(3-af) $)_{2} \mathrm{Cl}_{2}$; TCAP) in tumour models (L1210, L1210R, HL-60, HeLa, EJ, EJcisR) and human lymphocytes in vitro. Spectroscopic studies indicate that the 3-aminoflavone ligand is present in a chloride complex of trans-Pt(II). Furthermore, X-ray diffraction studies have confirmed that the central platinum(II) atom is four-coordinated by two nitrogen atoms of 3-aminoflavone ligand and two chloride anions. The compound is slightly less active than cisplatin against both the tested cell lines and cisplatin-resistant cell lines. Despite the fact that TCAP is slightly less active than cisplatin towards cancer-resistant cells (L1210R and EJcisR), it possesses a much lower resistance factor than cisplatin. Furthermore, trans$\mathrm{Pt}(3-\mathrm{af})_{2} \mathrm{Cl}_{2}$ was also less toxic for normal lymphocytes in comparison with cisplatin, which is a promising feature for a potential anticancer agent, as it should be toxic to tumours and safe for healthy tissues.

Even though TCAP has a lower cytotoxicity than cisplatin after 72 hours of treatment, a higher percentage of apoptotic cells is observed for TCAP than cisplatin in tested cell lines after shorter periods of time. It may indicate that TCAP activity has an earlier onset than cisplatin activity. This occurrence may not be completely unexpected, in that the trans and cisconformation compounds are likely to differ in their nature of binding with DNA. Apoptotic cell death involves a series of morphological and biochemical changes, including phosphatidylserine externalization and activation of caspase-3, and suggests that this process is dependent upon events associated with the loss of mitochondrial inner transmembrane potential $\left(\Delta \Psi_{\mathrm{m}}\right)$. In addition, the TCAP molecule may be more lipophilic than cisplatin ( $\log P$ respectively 2.26 vs. -4.58$)$, which may enhance its transmembrane transport. ${ }^{42}$

\section{Acknowledgements}

The authors thank Dr Manfred Zabel from Universität Regensburg for his helpful assistance with X-ray measurements. The authors thank Prof. Jan Reedijk (Leiden University) and Dr Maria Kasprzak (Medical University of Lodz) for critical reading of the manuscript. This work was supported partly by National Science Centre grant no. N N405 674040, Medical University of Lodz grants statute 502-03/3-016-02/502-34-041 (MF) and 503/3-016-02/503-01.

\section{Notes and references}

1 B. Rosenberg, V. Camp and T. Crigas, Nature, 1965, 205, 698.
2 J. Reedijk, Eur. J. Inorg. Chem., 2009, 10, 1303-1312.

3 G. Giaccone, Drugs, 2000, 59, 9.

4 B. Lippert, Cisplatin Chemistry and Biochemistry of a Leading Anticancer Drug, Wiley-VCH, New York, 1999.

5 H. S. Oberoi, N. V. Nukolova, A. V. Kabanov and T. K. Bronich, Adv. Drug Delivery Rev., 2013, 65, 16671685.

6 P. Heffeter, U. Jungwirth, M. Jakupec, C. Hartinger, M. Galanski, L. Elbling, M. Micksche, B. Keppler and W. Berger, Drug Resist. Updat., 2008, 11(1-2), 1-16.

7 J. Reedijk, Pure Appl. Chem., 2011, 83(9), 1709-1719.

8 M. A. Jakupec, M. Galanski and B. K. Keppler, Rev. Physiol., Biochem. Pharmacol., 2003, 146, 1.

9 J. Alemán, V. del Solar, A. Alvarez-Valdés, C. Ríos-Luci, J. M. Padrón and C. Navarro-Ranninger, MedChemComm, 2011, 2, 789-793.

10 J. J. Wilson and S. J. Lippard, Chem. Rev., 2014, 114, 44704495.

11 C. Pérez, C. V. Díaz-García, A. Agudo-López, V. del Solar, S. Cabrera, M. T. Agulló-Ortuño, C. Navarro-Ranninger, J. Alemán and J. A. López-Martín, Eur. J. Med. Chem., 2014, 76, 360-368.

12 U. Kalinowska-Lis, J. Ochocki and K. Matlawska-Wasowska, Coord. Chem. Rev., 2008, 252, 1328-1345.

13 V. del Solar, A. Quiñones-Lombraña, S. Cabrera, J. M. Padrón, C. Ríos-Luci, A. Alvarez-Valdés, C. NavarroRanninger and J. Alemán, J. Inorg. Biochem., 2013, 127, 128-140.

14 R. F. Murphy, E. Komlodi-Pasztor, R. Robey, F. M. Balis, N. P. Farrell and T. Fojo, Cell Cycle, 2012, 11(5), 963-973.

15 S. M. Aris and N. P. Farrell, Eur. J. Inorg. Chem., 2009, 10, 1293-1302.

16 D. Ravishankar, A. K. Rajora, F. Greco and H. M. I. Osborn, Int. J. Biochem. Cell Biol., 2013, 45(12), 2821-2831.

17 B. Kośmider and R. Osiecka, Drug Dev. Res., 2004, 63, 200211.

18 M. A. Callero, G. V. Suarez, G. Luzzani, B. Itkin, B. Nguyen and A. I. Loaiza-Perez, Int. J. Oncol., 2012, 41, 125-134.

19 B. Kośmider, K. Wyszynska, E. Janik-Spiechowicz, R. Osiecka, E. Zyner and J. Ochocki, Mutat. Res., 2004, 558, 93-110.

20 B. Kośmider, E. Zyner, R. Osiecka and J. Ochocki, Can. J. Physiol. Pharmacol., 2004, 82, 353-358.

21 B. Kośmider, R. Osiecka, E. Zyner and J. Ochocki, Drug Chem. Toxicol., 2005, 28, 231-244.

22 B. Kośmider, R. Osiecka, E. Ciesielska, L. Szmigiero, E. Zyner and J. Ochocki, Mutat. Res., 2004, 558, 169-179.

23 B. Kośmider, I. Zawlik, P. P. Liberski, R. Osiecka, E. Zyner, J. Ochocki and J. Bartkowiak, Mutat. Res., 2006, 604, 28-35.

24 B. Kośmider, E. Zyner, R. Osiecka and J. Ochocki, Mutat. Res., 2004, 563, 61-70.

25 A. J. Rybarczyk-Pirek, M. Małecka, Ł. Glinka and J. Ochocki, Acta Crystallogr., Sect. C: Cryst. Struct. Commun., 2007, 63, m410-m412. 
26 B. Zurowska, A. Erxleben, Ł. Glinka, M. Łeczycka, E. Zyner and J. Ochocki, Inorg. Chim. Acta, 2009, 362, 739-744.

27 J. Ochocki, M. Kasprzak, L. Chȩcińska, A. Erxleben, E. Zyner, L. Szmigiero, A. Garza-Ortiz and J. Reedijk, Dalton Trans., 2010, 39, 9711-9718.

28 A. Rybarczyk-Pirek, A. T. Dubis and S. J. Grabowski, Chem. Phys., 2006, 320, 247-258.

29 A. J. Rybarczyk, T. A. Olszak, M. Małecka and J. NawrotModranka, Acta Crystallogr., Sect. C: Cryst. Struct. Commun., 1999, 55, 1313-1315.

30 A. J. Rybarczyk-Pirek, S. J. Grabowski, M. Małecka and J. Nawrot-Modranka, J. Phys. Chem. A, 2002, 106, 1195611962.

31 A. J. Rybarczyk-Pirek, S. J. Grabowski and J. NawrotModranka, J. Phys. Chem. A, 2003, 107, 9232-9239.

32 A. J. Rybarczyk-Pirek and J. Nawrot-Modranka, Acta Crystallogr., Sect. E: Struct. Rep. Online, 2004, 60, o988-o990.
33 F. H. Allen, O. Kennard, D. G. Watson, L. Brammer, A. G. Orpen and R. Taylor, J. Chem. Soc., Perkin Trans. 2, 1987, S1-S19.

34 M. C. Etter, J. C. MacDonald and J. Bernstein, Acta Crystallogr., Sect. B: Struct. Sci., 1990, 46, 256-262.

35 M. Kasprzak, L. Szmigiero and J. Ochocki, Clin. Exp. Med. Lett., 2007, 48(3), 166-168.

36 Stoe \& Cie IPDS-II Software, Stoe \& Cie, Darmstadt, Germany, 2000.

37 G. M. Sheldrick, Acta Crystallogr., Sect. A: Fundam. Crystallogr., 2008, 64, 112-122.

38 L. J. Farrugia, J. Appl. Crystallogr., 1999, 32, 837-838.

39 M. Nardelli, Comput. Chem., 1983, 7, 95-98.

40 A. L. Spek, J. Appl. Crystallogr., 2003, 36, 7-13.

41 Cambridge Structural Database System, Cambridge Crystallographic Data Centre, Cambridge, UK, 2011.

42 http://www.molinspiration.com. 